\title{
Sources of Market Power among Firms in Sub-Saharan Africa: Do Institutions Matter in Competitive Policies?
}

\author{
Musa Abdu* and Adamu Jibir ${ }^{* *}$
}

\begin{abstract}
In the context of a high prevalence of both poverty among households and business failures among firms in the majority of Sub-Saharan African (SSA) countries, competition is seen as one of the viable tools for transforming and improving these economies. This can be achieved by boosting productivity, improving output markets, increasing innovation and promoting economic growth. This study examines the sources of market power among firms within a variety of institutional settings using a large sample of data from 23 SSA countries. Tobit panel models comprising both fixed and random effects are used to estimate the determinants of market power. The study reveals that a large number of firms control less than 5 percent of the market with a few firms controlling between 5 and 34 percent of the market. At the same time, there are a small number of firms controlling between 30 and 100 percent of the markets in Sub-Saharan Africa. The findings further show that economic and political institutions significantly matter in the determination of power among firms in SSA. However, the influence of institutions varies significantly depending on the type of institutions and regional differences.
\end{abstract}

Keywords: Competition, institutions, firm, market power, Sub-Saharan Africa.

JEL Classifications: D41, K20, L22, L41, O55.

\section{Introduction}

Firms have for centuries been committed to activities geared towards increasing market power ${ }^{1}$ by offering their buyers variety in the presence of competition. This favors consumers and is not seen as undesirable. However, the situation has changed in recent decades, as firms have tended to increase their profits through anti-competitive

\footnotetext{
* Department of Economics, Gombe State University, Nigeria.

*** Department of Economics, Gombe State University, Nigeria.

${ }^{1}$ Market power is the ability of a firm or group of firms to raise and maintain the price above the level that would prevail under a competitive market.
} 
measures - colluding with rivals, blocking the entry of new firms and other actions that make consumers worse off.

As a consequence, countries have enacted laws and policies aimed at regulating market power and the concentration of firms for societal wellbeing. Despite that, the market power and concentration of firms have been growing rapidly not only in capitalist societies but also in developing economies, like in regions of Africa, Asia and Latin America. ${ }^{2}$ According to the United Nations Conference on Trade and Development (UNCTAD) (2017), over the past two decades, market concentration increased steeply in terms of revenues, physical assets and other assets. Further, global mergers and acquisitions, a major factor affecting market power, have increased to $\$ 5$ trillion in 2015, almost double the average of 21 percent between 2010 and 2014 (UNCTAD, 2017).

Sub-Saharan Africa (SSA) is not an exception to this growing phenomenon. The World Bank (2016) posits that the majority of SSA countries are perceived to have a lower level of competition compared to other regions of the world and this causes high business risks generated by price control, vested interests and a high level of favoritism. Along the same lines, the World Economic Forum (2015) notes that more than 70 percent of SSA countries ranked in the bottom half on the perceived intensity of local competition. This has resulted in the prevalence imperfect markets characterized by lack of competition (Diez, Leigh \& Suchanan, 2018; Grau \& Hockmann, 2017; Memanova \& Mylonidis, 2019). This concern in SSA is largely overlooked but it is now resurfacing with various economic implications. Highly concentrated markets, if left unregulated and uncontrolled, can produce socially undesirable results such as higher prices and the survival of unproductive firms through blocking the entry of new firms (De Loecker \& Van Biesebroeck, 2016; Golombek, Irarrazabal \& Ma, 2018; UNCTAD, 2017). In addition, concern over increasing market concentration in the leading sectors of SSA countries is appropriate as it seems to have paved the way for rentier capitalism to the detriment of balanced and inclusive growth. The World Bank (2016) states that in the services sector, a single firm holds more than half the market share in over 50 percent of SSA countries. While some industries, such as power generating and transmission companies, railway companies and other utility providing industries may be natural monopolies (due to large fixed costs but very low marginal costs), there may still be the need for strong

\footnotetext{
2 The resulting harm of market power may extend beyond individual markets but would harm the economy as a whole in the form of slow economic growth, low productivity and increased inequality.
} 
legislation and government regulations to control exploitative industries. The World Bank (2016) observes that Africa has much to gain by promoting competition through various institutions.

The study of market power and concentration of firms in SSA, especially in the services sector, has been largely overlooked in the literature. The objective of this study is to examine empirically how the institutional setting and government regulations among SSA countries affect market power and the concentration of firms.

The contribution of this study is threefold: Firstly, it serves as one of the few pieces of research in this area particularly for the developing countries of SSA. Secondly, the study applied a micro-econometric approach which proves to be more robust and efficient in firm-level analysis. Lastly, using detailed firm-level data, we are able to study the sources of market power using a different set of institutional variables across different sub-regions in SSA, which enable us to examine the sources of market power in a comparative manner.

The subsequent sections of this paper are organized in five sections: Section 2 provides a theoretical framework and a related review of literature. Section 3 and 4 discuss the methodology and results and discussions are given in sections 3 and 4 followed by conclusions and policy recommendations in the last section.

\section{Theoretical Consideration and Review of Related Literature}

The underlying factors responsible for a decrease in competition and equivalent expansion in market power and monopolistic tendencies remain unclear in the economic literature. ${ }^{3}$ It is well known that the absence of competition tends to make consumers worse off because of the reduction of quality, increase in prices, and blocking the entry of new firms. Further, monopolistic power in the labor market may lead to restrictions in employment and the lowering of wages below what is obtainable in a competitive market (Berger, Herkenhoff \& Mongey, 2019; De Loecker \& Eeckhout, 2018; Naidu, Posner \& Wayl, 2018). It is a truism that competition brings uncountable benefits to consumers, workers, small businesses and other economic agents in a country (World Bank, 2016). These benefits can be achieved through the elimination of

\footnotetext{
${ }^{3}$ While there is evidence that market power exists but surprisingly there is little or no evidence of the pattern of market power on the aggregate economy and the role of institutions in reducing monopolistic tendencies (De Loecker \& Van Biesebroeck, 2017).
} 
anti-competitive practices with sound legislation which, in most cases, are either absent or ineffective in most developing economies. ${ }^{4}$ Government action can help to check market and encourage competition through anti-trust authorities and other relevant policies. ${ }^{5}$

Building on existing empirical and theoretical studies, there are many indices used in measuring market power and the concentration of firms in the literature. Some of these indices include a concentration ratio, which is mostly applied when there are large firms; the entropy index developed by Hart (1971); the Linda index; Horvath index developed by Horvath (1970); the Lerner index propounded by Lerner (1934); the Hirschman-Herfindhal index proposed by Herfindhal (1950) and Hirschman (1964), among others. Among all these indices, the HirschmanHerfindhal index and concentration ratio have been the most widely used for the empirical analysis of market power.

Empirical studies specifically aimed at the effects of institutional policies and regulations on market power are extremely scarce. Most studies are skewed towards the effects of institutions on the firm's growth and in a broader sense on the general wellbeing of the economy (example include: Henrekson, 2005; Henrekson \& Rosenberg, 2001; Klapper, Laeven \& Rajan, 2006). There are a few empirical studies (like: Davidsson \& Henrekson, 2002; Henrekson \& Johansson, 1999; Memanova \& Mylonidis, 2019) that provide insight on institutions that harmonize the activities of different actors with competencies which can bring about high economic growth and a competitive economy. Bresnahan (1989) finds that it is likely that institutional policies at the industry level will affect firm conduct and concentration. Formal institutions, both underlying and specific, provide the context and environment within which firms operate (Rodrik, 2008). ${ }^{6}$

Using panel data from U.S. airports, Bilotkash and Lakew (2014), analyze the sources of market power in the U.S. airline industry, and find that airport dominance is a more important source of market power than route dominance. Van Dender (2007) examines the relationship between airport level fares and concentration using 55 airports in the US and the

\footnotetext{
${ }^{4}$ The benefits can be achieved even with a few or a single firm in the market provided there are credible threats of entry of new firms (Cabral, 2000; Dixit, 1980).

${ }^{5}$ However, it is paramount to know that consumers are not necessarily worse off when a firm's market power/market share increases as sometimes it may increase due to innovations which in turn increases the demand for the firm's products and services.

${ }^{6}$ Political, judicial and economic regulations and policies are important mechanisms for managing market power and firms concentration. Moreover, whether or not institutional policies are effective in regulating market power and firm's concentration to a large extent depends on their settings and efficacy.
} 
results reveal an insignificant relationship between them. On the contrary, Borenstein, (1991) finds that an airline with a dominant position has greater market power. Also, Bilotskash (2007) establishes similar evidence that dominant firms control prices on international routes.

On the other hand, a substantial literature argues that competition among firms benefits consumers through lower prices (De Loecker \& Van Biesebroeck, 2017; Kovacic \& Shapiro, 2000; Memanova \& Mylonidis, 2019). These benefits can also be greater product variety, quality and innovations which improve productivity and living standards (Aghion, Bloom \& Blundell, 2005; Chen \& Yu, 2018; Dunn \& Shapiro, 2012; Memanova \& Mylonidis, 2019). Market power is associated with lower economic growth, lower savings and investment and higher costs of financial intermediation (see Asongu, Nwachukwu \& Tchamyou, 2016; Berger, Herkenhoff \& Mongey, 2019; De Loecker \& Eeckhout, 2018; De Loecker \& Eeckhout, 2017; Morrison 1990; Naidu, Posner \& Wayl, 2018).

Ciriani and Lebourges (2016) examine the effects of market power on economic growth and find that economic policies tend to limit the incentives and capabilities to invest in new technologies. Promoting competition goes beyond the enforcement of antitrust policies and laws; it is more appropriate when pro-competitive policies are enhanced.

Asongu, Le-roux and Tchamyou (2019) further stress that both consumers and producers can gain and lose depending on the circumstances. For instance, from the perspective of the consumer, market power is associated with efficiency because the consumer's marginal value is more than the market price. On the other hand, from the side of the producer, when the marginal cost of production is substantially lower than the supply price, the producer will make considerable gain. Navo (2001) investigates the extent to which firms exercise market power in ready-toeat cereal industries and found that the demand and production approaches mainly agree on the mean level of mark-ups in the industry. Cruz-Garcia, de Guevara and Maudos (2017), in their analysis of market power, observe that the disparity in market power among banks in the Eurozone has decreased over time partly due to the convergence in average levels of market power and concentration.

Further, some research studies indicate that labor market power has contributed to wage inequality and economic stagnation (Berger, Herkenhoff \& Mongey, 2019; Naidu, Posner \& Weyl, 2018). This suggests that many labor markets around the world are not competitive but instead 
exhibit considerable market power enjoyed by the employers, who use their market power to suppress wages.

Sylos-Labini (1967) find that the degree of competition or market power in any industry mainly depends on the barriers to entry of new firms, rather than the incumbent firm's size. Further, Cotterill (1986) find that the emergence of market power is mainly associated with technological factors rather than institutional factors. Vickers (2005) shows that the weakness of antitrust legislation in the US and parts of Europe has significantly contributed to the emergence of market power in recent decades. Asongu et. al, (2016) in their study of the role of information in reducing market power reveals that information-sharing offices completely neutralize the negative effect of market power on financial access. Other studies on market power and the banking industry show a strong positive correlation between foreign bank ownership and market power (Delis, Kokas \& Ongena, 2016; Asongu \& Odhiambo, 2019; Asongu \& Biekpe, 2018; Akande, 2018). Egarius and Weill (2016) in their analysis of market power and switching costs in the banking industry using data for France, Germany and Italy, find a positive relationship between switching costs and market power. On the effect of mergers on market power, Kim and Singal (1993) found that prices increased for routes served by the merging firms relative to routes unaffected by the mergers. Liski and Montero (2011) show that a dominant firm tends to use its market power to increase prices. Hintermann (2011) shifts the focus away from exclusionary manipulation and show that a dominant firm with market power will manipulate prices for higher gains. Asker, Wexler and Loecker (2017) examine the effect of market power on the misallocation of resources in oil production. They found that there is substantial productive inefficiency due to market power.

The entry of new firms in the market is also found to have a significant effect on monopolistic power (Adebayo \& Adeniij, 2018: Dafny, 2005; Goolsbee \& Syverson, 2008; Seamans, 2012; Tenn \& Wendling, 2014). It is important to note that the presence of many firms in a market does not guarantee competition. Sometimes firms collude to create market power (see Ajide, Bankefa \& Ajisafe, 2018; Milgrom \& Roberts, 1982). There is also evidence of increasing market concentration around the world. For example, Gaynor, Ho and Town (2015) reveal that between the early 1990s and 2006, the average Herfindahl-Hirschman Index (HHI) for hospitals increased by about 50 percent. In the same vein, Prater et al. (2012) found an increase in railroad market concentration between 1985 and 2007 in the US. 
Generally, from the above survey of literature, it is clear that the question of the appropriate measures and sources of market power is not definitively answered and there are only a few studies that fully explore the nexus between institutions, monopolistic tendencies and market concentration - particularly for SSA countries. Thus, it is useful to look at the role of political, economic and legal institutions on monopolistic tendencies and the ability of firms to gain market power.

\section{Methodology of the Study}

\subsection{Data Sources}

The study used the Enterprise Panel Survey data sets by the World Bank (2017) for 23 Sub-Saharan Africa countries. The countries are selected based on the availability of data and are representative of the diversity of national incomes in SSA. The merged data set is an unbalanced panel with coverage ranging between 2003 and 2017 as described in appendix B. The Enterprise Survey is nationally representative of the various business establishments across the countries, involved mainly in manufacturing, retail and other services. Data was collected on firms' experiences and enterprises' perception of the environment in which they operate and focus on several factors that shape the business environment. These factors either constrain the firms' performance, or are viewed as sine qua non for the firms' prosperity. Data on economic institutions, institutionalized democracy and market size were sourced from the Index of Economic Freedom by The Heritage Foundation (2003-2017), Polity IV data set by the Centre for Systemic Peace (2003-2017) and World Development Indicators by the World Bank (2003-2017). The institutional variables are country average values reported by the data collection agencies.

\subsection{Measures of Market Power}

There are many measures of concentration propounded in industrial economics as highlighted in section 2. As a result, Pavic, Galetic and Piplica (2016) categorized them into two main groups. The first group is made up of measures that are easy to understand and simple to compute. The Concentration Ratio (CR) and Herfidahl-Hircschman Index (HHI) are the examples of this first group. In contrast, the second group is very complex and designed to serve particular purposes which include the Lerner index, Linda index, among others. This study used the first group's measures, particularly $\mathrm{CR}$ and $\mathrm{HHI}$ because they are easy to calculate, interpret and capture many aspects of market concentration. The CR is 
computed by taking the proportion of output of the $k$ biggest firms in the industry. The CR is calculated as:

$$
C R_{k}=\sum_{i}^{k} S_{i}
$$

Where $k=4,8,10, \ldots \ldots, 20, \ldots \ldots$ and $S_{i}$ is the market share of the $i^{\text {th }}$ firm in descending order. The CR usually takes the four biggest firms $(k=4)$ but if the total number of firms operating in the market is large, then an 8-firm or even 20-firm CR is used to assess the market concentration. The CR lies between 0 and 100 percent; 0 is a perfectly competitive case and 100 percent is seen as a monopoly situation. Although the measure is the simplest one, it has shortcomings like failing to indicate the presence or absence of potential entry and it does not measure local or regional market power. Thus, we also calculate the HHI index partly to complement the CR index and obtain a robust analysis of the subject matter. The group of measures, especially HHI, is also highly dynamic as it changes when there is new entry or exit into the market, and is a well-accepted indicator of competition (Brezina, Pekar, Cickova \& Reiff, 2016).

$\mathrm{HHI}$ is the sum of squares of the market shares of all firms in the industry or market. It is the most widely used measure of market concentration and has been widely applied in the United States to enforce anti-trust (competition) laws on firms (Bikker \& Haff, 2002; Barthwal, 2010). Symbolically $\mathrm{HHI}$ is calculated as:

$$
H H I=\sum_{i}^{n} S_{i}^{2}
$$

Where $S_{i}=q_{i} / Q, q$ is the sales of the $i^{\text {th }}$ firm, $Q$ is total output of all firms in the market and $n$ is the total number of firms. HHI lies between 0 and 1 . It considers all firms and their relative sizes, and as such, it is popularly used. In this study, HHI is computed and used relative to industry, year and country. Generally, the choice of the CR and HHI indices is motivated by the fact that they are the most widely used approaches of measuring market power - especially when the market is characterised by a significant degree of market power and monopolistic tendencies (Kwoka, 1985). ${ }^{7}$

\subsection{Model Specification and Estimation Technique}

Generally, the sources of monopoly power among firms are numerous. Mankiw (2012) and Reynolds (2011) note that market power

\footnotetext{
${ }^{7}$ For details see Gaynor, Ho \& Town (2015).
} 
comes from the following sources: natural monopoly through unique sources of raw materials, large sunk costs, market size, government ownership and legislation. Thus, the baseline model for this study could be specified as in equation 3:

$$
\text { mktpower }_{i t}=f\left(\text { rmat }_{i t}, \text { mktsize }_{i t}, \text { govown }_{i t}, \operatorname{cost}_{i t}, \text { age }_{i t}\right)
$$

Where mktpower is the market power, rmat is the expenditure on raw materials as a proportion of sales, govown, the "government ownership," cost is a vector of costs of production (capital and labor) and age is the years of the firm's operation. Equation (3) could be modified to capture other variables as in equation 4 :

$$
\begin{aligned}
\text { mktpower }_{i t}= & \delta_{0}+\delta_{1} \text { age }_{i t}+\delta_{2} \text { cost }_{i t}+\delta_{3} \text { rmat }_{i t}+\delta_{4} \text { mktsize }_{i t}+ \\
& \delta_{5} \text { govown }_{i t}+\delta_{7} \text { inst }_{i t}+\mu_{i t}
\end{aligned}
$$

where exprt is a dummy for the firm's exports, and inst is a vector of economic, legal and political institutions. $\mu$ is the error term and it represents firm $i$ in time $t$. The choice of these control variables is consistent with the recent market power literature (Chen \& Yu, 2018; Diez, Leigh \& Suchanan, 2018; Grau \& Hockmann, 2018; Memanova \& Mylonidis, 2019).

This study applied a Tobit panel regression model to estimate the determinants of market power in Sub-Saharan Africa. The model is selected because it is the most suitable when there is either left- or rightcensoring in the dependent variable (also known as censoring from below and above, respectively). Besides, the model is also chosen because $\mathrm{HHI}$ is truncated between 0 and 1 while CR lies between 0 and 100 percent. The Random effects Tobit model is estimated given the inconsistency of the fixed effects Tobit estimator as observed by Cameron and Trivedi (2005). The model is specified in equation 5 :

$$
\text { mktpower }{ }_{i t}^{*}=\beta_{0}+\beta_{n} \mathrm{x}_{i t}+v_{i t}+\mu_{i t}
$$

Where mktpower $_{i}=0$ if mktpower $_{i}^{*} \leq 0$ and mktpower $_{i}=$ mktpower $_{i}^{*}$ if mktpower ${ }_{i}^{*}>0, x_{i t}$ is a vector of explanatory variables and $v_{i t}$ is a random effect and $\mu_{i t}$ is an error term of the ith firm in time $t$.

\section{Results and Discussions}

Appendix A reports the definitions of the variables used in the analysis while Appendix B contains the descriptive statistics of the variables. Appendix $C$ lists the countries and years of survey. Appendix D presents 
partial correlations between measures of market power and explanatory variables and the results show that there is significant correlation with the exception of market size, which is only moderately correlated with the HHI index. This means that the possibility of reverse causality between the variables is very low. Table 1 reports the distribution of market power among firms based on their types, sub-regions and sizes. The table reveals that the manufacturing, retail and service firms hold sizeable shares of their respective markets, which are all less than 0.50 or 50 percent. Specifically, the average $\mathrm{HHI}$ of manufacturing firms is just 0.11 , which is far lower than those of retail and services firms of 0.23 and 0.21 respectively. However, there are still a few manufacturing, retail and service firms that control more than 80 percent of the markets. This can affect the efficiency of markets due to a significant probability of monopolistic behavior (see Akande, 2018). Again, when the firms were further disaggregated (using the CR), it is observed that the four biggest manufacturing, retail and service firms hold sizeable shares of their respective markets. But then again, there are some firms among the four biggest manufacturing firms that hold about 97 percent of the market. This means that there is a strong element of high market concentration, possibly by way of collusion or cartelization among the firms (see Chen \& Yu, 2018).

Table 1 suggests further that, in terms of average HHI, firms from all regions hold a moderate share of the markets of less than 0.02 or 2 percent, with Central African firms holding the largest average share of 0.01 or 1 percent. Conversely, Western Africa has a few firms controlling up to 34 percent of the markets. To confirm this, the firms in the regions were also disaggregated; it is again found that the average market share held by the four biggest firms in the regions is less than 40 percent. Yet, some of the biggest firms hold about 100 percent of some markets in Eastern and Western Africa. This is in conformity with the result obtained by Adebayo and Adeniji (2018). It implies that some markets in Eastern, Central and Western Africa are highly monopolized, which could be due to a weak institutional framework. On the other hand, market power is lower in Southern Africa, and this may be the result of relatively strong institutions in the region. This finding is in line with the results obtained by Roberts (2004) and Sitko, Burke and Jayne (2018) in their studies on market power and competition in southern Africa.

Additionally, the average market shares (using HHI) held by micro, small, medium and large firms are also modest because the average shares are below 0.02 or 2 percent of the market. Nevertheless, some of the micro, small, medium and large firms control up to 34 percent of their respective markets. 
Table 1: Distribution of Market Power in Sub-Saharan Africa

\begin{tabular}{|c|c|c|c|c|c|c|c|c|}
\hline \multirow[t]{2}{*}{ Firm-Type } & \multicolumn{2}{|c|}{ Distribution } & \multicolumn{2}{|c|}{$\begin{array}{c}\text { Average } \\
\text { Market Share }\end{array}$} & \multicolumn{2}{|c|}{$\begin{array}{c}\text { Minimum } \\
\text { Market Share }\end{array}$} & \multicolumn{2}{|c|}{$\begin{array}{c}\text { Maximum } \\
\text { Market Share }\end{array}$} \\
\hline & Frequency & Percentage & HHI & CR (\%) & HHI & CR (\%) & HHI & CR (\%) \\
\hline \multicolumn{9}{|c|}{ By Firm-Type } \\
\hline Manufacturing & 10,915 & 48.34 & 0.004 & 38.75 & 0.001 & 16.05 & 0.03 & 97.44 \\
\hline Retail & 5,294 & 23.45 & 0.01 & 35.76 & 0.001 & 19.64 & 0.34 & 42.48 \\
\hline Service & 6,370 & 28.21 & 0.01 & 36.50 & 0.001 & 13.28 & 0.04 & 46.20 \\
\hline \multicolumn{9}{|c|}{ By Region } \\
\hline Eastern Africa & 9,016 & 26.87 & 0.005 & 39.33 & 0.002 & 19.64 & 0.02 & 100 \\
\hline Central Africa & 2,604 & 7.76 & 0.01 & 38.64 & 0.01 & 37.01 & 0.02 & 40.74 \\
\hline Southern Africa & 1,961 & 5.84 & 0.005 & 38.99 & 0.002 & 37.01 & 0.04 & 40.74 \\
\hline Western Africa & 19,970 & 59.52 & 0.004 & 37.82 & 0.0002 & 8.64 & 0.34 & 100 \\
\hline \multicolumn{9}{|c|}{ By Firm-Size } \\
\hline Micro & 266 & 0.95 & 0.01 & 37.01 & 0.001 & 0 & 0.08 & 37.01 \\
\hline Small & 17,421 & 61.89 & 0.004 & 38.85 & 0.0002 & 8.64 & 0.34 & 100 \\
\hline Medium & 7,752 & 27.54 & 0.004 & 37.01 & 0.0002 & 8.64 & 0.34 & 100 \\
\hline Large & 2,708 & 9.62 & 0.01 & 40.74 & 0.0002 & 8.64 & 0.08 & 97.44 \\
\hline Total & - & - & 0.01 & 38.20 & 0.0002 & 8.64 & 0.34 & 100 \\
\hline
\end{tabular}

Source: Authors' Calculations using World Bank Enterprise Survey Datasets.

When the CR is considered, the four biggest firms among micro, small, medium and large firms hold significant shares of their markets of about 41 percent and the four biggest firms hold between 97 and 100 percent of the markets. This is strong evidence for the existence of monopolies which also threatens social welfare and efficiency of markets.

Table 1 and Figure 1 depict that a large number of the firms control less than 0.2 or 20 percent of the markets with a few firms holding between 20 and 60 percent of the markets. But there are a small number of firms holding between 70 and 99 percent of the markets in Sub-Saharan Africa.

\section{Figure 1: Market Power Base on Herfidahl-Hircschman Index (HHI)}

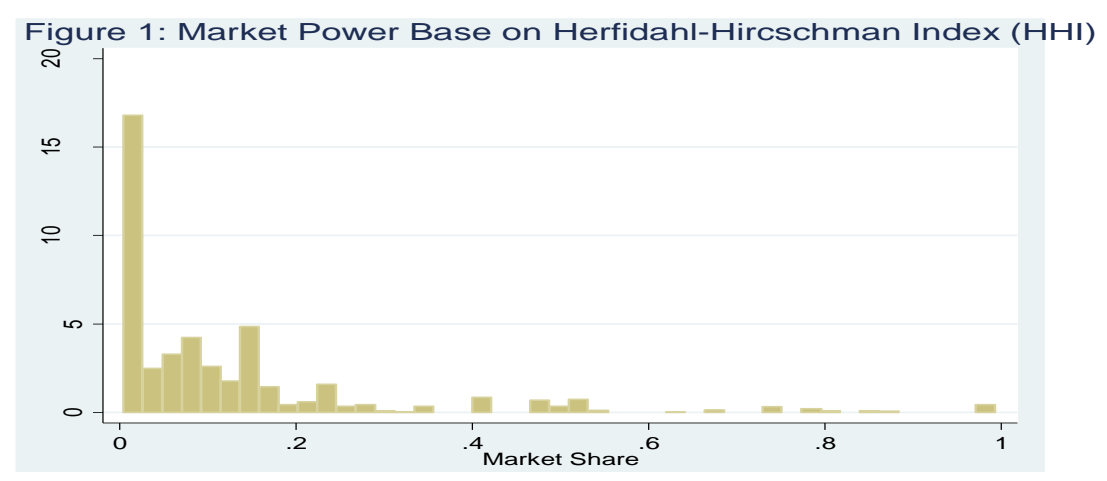

Source: Authors' Calculations. 
This signals the presence of monopolies in the region. The monopolies may have taken advantage of the high cost of doing business in the region to occupy the markets. This provides support for the findings of studies by Chen and Yu (2018), Adebayo and Adeniji (2018) and Akande (2018).

\section{Figure 2: Market Power Based on Concentration Ratio (CR) in SSA}

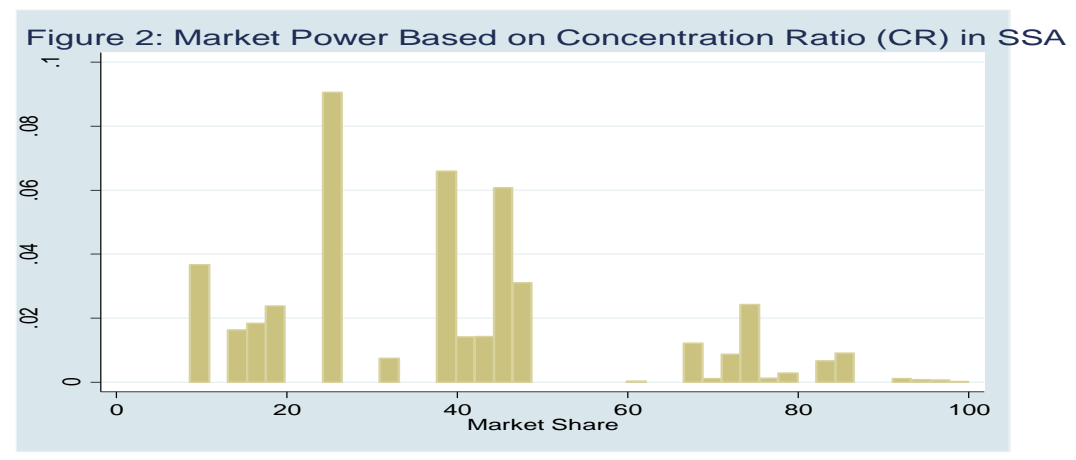

Source: Authors' Calculations.

Figure 2 shows that the four biggest firms in SSA control between 10 and 50 percent of the markets with the four biggest firms holding the equivalent of 70-100 percent of the markets. This is a typical case of collusion, which is detrimental to competition in SSA as argued by Roberts (2004) and Sitko, Burke and Jayne (2018).

Table 2 reports Panel Tobit regression models on sources of market power in SSA using HHI consisting of an unconditional ${ }^{8}$ fixed effect, random-effect and pooled Tobit regression models. The coefficients of both the fixed-effect and random-effect Tobit models appear to be almost the same in terms of signs, size and significance. This implies that we cannot reject the random-effect Tobit regression model. Again, the rho estimate of the random-effect model suggests that the panel-level variance component is important, and the panel estimator is different from the pooled estimator. This means the random-effect Tobit model is appropriate here. In Table 2, the results of the random effects model indicate that only institutionalized democracy matters in determining the market power of

\footnotetext{
${ }^{8}$ An unconditional fixed-effect Tobit regression model is estimated due to the lack of the formal process of estimating the conditional one. Following Zambrano (2005), we fitted the fixed-effect Tobit model by estimating linear Tobit with the time-variant factor since there many firms $(33,551)$ and including the cross-sectional units to capture firm-level effects would create a problem. However, this estimation does not also give room for estimating the Hausman test.
} 
firms in SSA and it seems to have increased market dominance of firms in the region by about 0.004 percent, and this may not be unconnected with political patronage and lobbyists' activities.

Additionally, the random effects model in Table 2 incorporates interaction terms and the results imply that when democracy becomes more institutionalized and firm size increases simultaneously, the market power of the firms decreases and this may be due to competition. This is so because many newer firms might have grown strong enough to compete both legitimately and illegitimately with the existing ones. Further, the results show that as democracy becomes more institutionalized and firm exports increase, then such firms tend to dominate the market. This, of course, could be linked to the expansion of the political networks of such firms and the possibility of engaging in collusive activity at both the local and international markets. Among the controls in the random-effect Tobit model, significant variables include age, cost of labor, firm size, domestic market size, imported raw materials as a proportion of sales and a more expansive market-size variable created through the interaction between domestic market size and exporting status. 
Table 2: Sources of Herfidahl-Hircschman-Index-Based Market Power in SSA

\begin{tabular}{|c|c|c|c|}
\hline Variables & Unc. FE Tobit & RE Tobit & Pooled Tobit \\
\hline Age & $\begin{array}{c}-1.65 \mathrm{e}-05^{* * *} \\
(4.00 \mathrm{e}-06)\end{array}$ & $\begin{array}{c}-1.65 e-05^{* * * *} \\
(4.00 e-06)\end{array}$ & $\begin{array}{c}-2.48 \mathrm{e}-05^{* * *} \\
(4.46 \mathrm{e}-06)\end{array}$ \\
\hline Lab cost $(\log )$ & $\begin{array}{c}0.000280^{* * * *} \\
(2.91 \mathrm{e}-05)\end{array}$ & $\begin{array}{c}0.000281^{* * *} \\
(2.91 \mathrm{e}-05)\end{array}$ & $\begin{array}{c}8.66 \mathrm{e}-05^{* * *} \\
(2.99 \mathrm{e}-05)\end{array}$ \\
\hline Phy capital (log) & $\begin{array}{c}5.15 \mathrm{e}-05 \\
(3.15 \mathrm{e}-05)\end{array}$ & $\begin{array}{c}5.17 \mathrm{e}-05 \\
(3.15 \mathrm{e}-05)\end{array}$ & $\begin{array}{l}0.000122^{* * *} \\
(3.55 \mathrm{e}-05)\end{array}$ \\
\hline Firm size & $\begin{array}{l}-0.00078^{* * *} \\
(0.000249)\end{array}$ & $\begin{array}{c}-0.00078^{* * *} \\
(0.000249)\end{array}$ & $\begin{array}{c}-0.000673^{* *} \\
(0.000279)\end{array}$ \\
\hline Sales' Prop. of Imported r/w & $\begin{array}{l}6.56 \mathrm{e}-06^{* * * *} \\
(2.03 \mathrm{e}-06)\end{array}$ & $\begin{array}{l}6.62 \mathrm{e}-06^{* * *} \\
(2.03 \mathrm{e}-06)\end{array}$ & $\begin{array}{c}2.14 \mathrm{e}-05^{* * *} \\
(2.27 \mathrm{e}-06)\end{array}$ \\
\hline Exporting status & $\begin{array}{c}0.00948^{* * * *} \\
(0.00297)\end{array}$ & $\begin{array}{c}0.00950^{* * *} \\
(0.00297)\end{array}$ & $\begin{array}{l}0.0164^{* * *} \\
(0.00334)\end{array}$ \\
\hline Domestic Market size & $\begin{array}{l}-0.00204^{* * *} \\
(8.24 \mathrm{e}-05)\end{array}$ & $\begin{array}{c}-0.00204^{* * *} \\
(8.24 \mathrm{e}-05)\end{array}$ & $\begin{array}{l}-0.00221^{* * *} \\
(6.80 \mathrm{e}-05)\end{array}$ \\
\hline Govt ownership & $\begin{array}{l}-0.000364 \\
(0.000351)\end{array}$ & $\begin{array}{l}-0.000364 \\
(0.000351)\end{array}$ & $\begin{array}{l}-0.000253 \\
(0.000394)\end{array}$ \\
\hline Domestic Priv. Own & $\begin{array}{l}-0.000104 \\
(0.000174)\end{array}$ & $\begin{array}{l}-0.000103 \\
(0.000174)\end{array}$ & $\begin{array}{l}-0.000367^{*} \\
(0.000195)\end{array}$ \\
\hline Econ inst. & $\begin{array}{c}2.51 \mathrm{e}-05 \\
(1.64 \mathrm{e}-05)\end{array}$ & $\begin{array}{c}2.50 \mathrm{e}-05 \\
(1.64 \mathrm{e}-05)\end{array}$ & $\begin{array}{c}-6.97 \mathrm{e}-05^{* * *} \\
(1.79 \mathrm{e}-05)\end{array}$ \\
\hline Court sys fairness & $\begin{array}{l}-1.43 e-05 \\
(5.66 e-05)\end{array}$ & $\begin{array}{l}-1.47 \mathrm{e}-05 \\
(5.67 \mathrm{e}-05)\end{array}$ & $\begin{array}{c}-0.000228^{* * *} \\
(6.30 \mathrm{e}-05)\end{array}$ \\
\hline Inst. Democ. & $\begin{array}{l}4.04 \mathrm{e}-05^{* * *} \\
(7.98 \mathrm{e}-06)\end{array}$ & $\begin{array}{l}4.04 \mathrm{e}-05^{* * *} \\
(7.98 \mathrm{e}-06)\end{array}$ & $\begin{array}{c}3.42 \mathrm{e}-05^{* * *} \\
(8.54 \mathrm{e}-06)\end{array}$ \\
\hline Market size * exporting status & $\begin{array}{l}-0.00059^{* * *} \\
(0.000169)\end{array}$ & $\begin{array}{c}-0.00059^{* * *} \\
(0.000169)\end{array}$ & $\begin{array}{c}-0.000989^{* * * *} \\
(0.000190)\end{array}$ \\
\hline Econ inst. ${ }^{*}$ firm size & $\begin{array}{c}3.79 \mathrm{e}-06 \\
(4.54 \mathrm{e}-06)\end{array}$ & $\begin{array}{c}3.81 \mathrm{e}-06 \\
(4.54 \mathrm{e}-06)\end{array}$ & $\begin{array}{c}6.42 \mathrm{e}-06 \\
(5.10 \mathrm{e}-06)\end{array}$ \\
\hline Econ inst. * exporting status & $\begin{array}{l}-1.76 e-06 \\
(2.93 e-06)\end{array}$ & $\begin{array}{l}-1.76 e-06 \\
(2.93 e-06)\end{array}$ & $\begin{array}{l}-1.77 \mathrm{e}-06 \\
(3.31 \mathrm{e}-06)\end{array}$ \\
\hline Inst. Democ. * exporting status & $\begin{array}{l}3.88 \mathrm{e}-05^{*} \\
(2.10 \mathrm{e}-05)\end{array}$ & $\begin{array}{l}3.87 \mathrm{e}-05^{*} \\
(2.10 \mathrm{e}-05)\end{array}$ & $\begin{array}{l}3.03 e-05 \\
(2.37 e-05)\end{array}$ \\
\hline Inst. Democ. ${ }^{*}$ firm size & $\begin{array}{l}-0.00024^{* * *} \\
(5.78 \mathrm{e}-05)\end{array}$ & $\begin{array}{c}-0.00024^{* * *} \\
(5.79 \mathrm{e}-05)\end{array}$ & $\begin{array}{c}-0.000180^{* * *} \\
(6.37 \mathrm{e}-05)\end{array}$ \\
\hline Southern Africa & $\begin{array}{l}-0.00275^{* * *} \\
(0.000214)\end{array}$ & $\begin{array}{c}-0.00275^{* * *} \\
(0.000214)\end{array}$ & $\begin{array}{c}-0.00295^{* * *} \\
(0.000193)\end{array}$ \\
\hline Eastern Africa & $\begin{array}{l}-0.000576 \\
(0.000363)\end{array}$ & $\begin{array}{l}-0.000570 \\
(0.000363)\end{array}$ & $\begin{array}{c}-0.00200^{* * *} \\
(0.000331)\end{array}$ \\
\hline Western Africa & $\begin{array}{l}-0.00081^{* * *} \\
(0.000247)\end{array}$ & $\begin{array}{l}-0.0008^{* * *} \\
(0.000247)\end{array}$ & $\begin{array}{c}-0.000565^{* * *} \\
(0.000214)\end{array}$ \\
\hline Constant & $\begin{array}{l}0.0741^{* * *} \\
(0.00188)\end{array}$ & $\begin{array}{l}0.0442^{* * *} \\
(0.00385)\end{array}$ & $\begin{array}{l}0.0484^{* * *} \\
(0.00161)\end{array}$ \\
\hline Sigma u & & $\begin{array}{l}0.0114^{* * *} \\
(0.00244)\end{array}$ & \\
\hline Sigma e & $\begin{array}{l}0.00616^{* * *} \\
(3.78 \mathrm{e}-05)\end{array}$ & $\begin{array}{l}0.00616^{* * *} \\
(3.78 \mathrm{e}-05)\end{array}$ & $\begin{array}{l}0.00696^{* * *} \\
(4.27 \mathrm{e}-05)\end{array}$ \\
\hline Rho & & $\begin{array}{c}0.7744^{* * *} \\
(0.0748)\end{array}$ & \\
\hline Time-Variant Factor & X & - & - \\
\hline Observations & 13,295 & 13,295 & 13,295 \\
\hline Number of year & 11 & 11 & 11 \\
\hline
\end{tabular}

Source: Authors' Calculations.

Note: Standard errors in parentheses ${ }^{* * *} \mathrm{p}<0.01,{ }^{* *} \mathrm{p}<0.05,{ }^{*} \mathrm{p}<0.1$. 
In particular, the model shows that as the firm ages, market power decreases by 0.002 percent meaning that the age of the firms in SSA does not increase market power. This may be due to lack of dynamism and competitiveness of the firms in SSA that adhere to a given strategy of doing business because of low technological development. Domestic market size is also observed to have a negative effect on market power in SSA, that is, as domestic market size expands a firm's market power reduces by 0.204 percent. This implies that a large market makes it less likely for any firm to strive to occupy the market. In order to see the effect of market size across exporting and non-exporting firms, an interaction term of market size and exporting status was created, which shows that market size generally reduces the market power of firms by an additional 0.057 percent when they are exporters.

Furthermore, exporting firms tend to have greater market power, by 0.95 percent, which could be due to high competitive advantage and access to more opportunities than non-exporting firms in SSA. Imported raw materials as a proportion of sales positively affect the firms' market power, which indicates that an increase in the proportion of imported raw materials leads to rise in market power by 0.001 percent. The ability to import (unique) raw materials gives such firms a competitive edge, and may result in greater market power. It is also shown in Table 2 that as the size of the firms increases, the tendency toward market power decreases by 0.078 percent, which could also be linked to improvement in competition as more firms are able to compete with the existing market leaders. As the labor cost goes up, the firms' market power also increases and this is so because the high cost of doing business may discourage some firms from producing goods and services. Finally, firms from Southern, Eastern and Western Africa have less market power than those from Central Africa.

Table 3 reports Panel Tobit regression models on sources of market power in SSA using the Concentration Ratio of the four biggest firms consisting of unconditional fixed-effect, random-effect and pooled Tobit regression models. Again, the unconditional fixed-effect Tobit regression model is estimated due to lack of a formal process of estimating the conditional one. 
Table 3: Sources of Concentration Ratio-based Market Power in SSA

\begin{tabular}{|c|c|c|c|}
\hline Variables & Unc. FE Tobit & RE Tobit & Pooled Tobit \\
\hline \multirow[t]{2}{*}{ Age } & $0.0151^{* * *}$ & $0.0151^{* * *}$ & $0.00980^{* * *}$ \\
\hline & $(0.00225)$ & $(0.00225)$ & $(0.00264)$ \\
\hline \multirow[t]{2}{*}{ Lab cost (log) } & $0.0939^{* * *}$ & $0.0929^{* * *}$ & $-0.191^{* * *}$ \\
\hline & $(0.0163)$ & $(0.0163)$ & $(0.0176)$ \\
\hline \multirow[t]{2}{*}{ Phy capital (log) } & $0.0483^{* * *}$ & $0.0482^{* * *}$ & $0.0536^{* *}$ \\
\hline & $(0.0177)$ & $(0.0177)$ & $(0.0210)$ \\
\hline \multirow{2}{*}{ Firm size } & $0.805^{* * *}$ & $0.807^{* * * *}$ & $1.231^{* * *}$ \\
\hline & $(0.139)$ & $(0.139)$ & $(0.164)$ \\
\hline \multirow[t]{2}{*}{ Sales' Prop. of Imported r/w } & $-0.00841^{* * *}$ & $-0.00843^{* * *}$ & $-0.00733^{* * *}$ \\
\hline & $(0.00115)$ & $(0.00115)$ & $(0.00135)$ \\
\hline \multirow[t]{2}{*}{ Exporting status } & 0.527 & 0.535 & $6.208^{* * *}$ \\
\hline & (1.683) & $(1.684)$ & (1.995) \\
\hline \multirow{2}{*}{ Domestic Market size } & $0.959 * * *$ & $0.959^{* * *}$ & $0.557^{* * *}$ \\
\hline & $(0.0478)$ & $(0.0478)$ & $(0.0408)$ \\
\hline \multirow[t]{2}{*}{ Govt ownership } & -0.206 & -0.207 & $-0.446^{*}$ \\
\hline & $(0.197)$ & $(0.197)$ & $(0.233)$ \\
\hline \multirow[t]{2}{*}{ Domestic Priv. Own } & $0.615^{* * *}$ & $0.615^{* * *}$ & $0.616^{* * *}$ \\
\hline & $(0.0976)$ & $(0.0977)$ & $(0.116)$ \\
\hline \multirow[t]{2}{*}{ Econ inst. } & $0.0335^{* * *}$ & $0.0337^{* * *}$ & $0.0717^{* * *}$ \\
\hline & $(0.00916)$ & $(0.00916)$ & $(0.0106)$ \\
\hline \multirow[t]{2}{*}{ Court sys fairness } & $0.136^{* * *}$ & $0.136^{* * *}$ & $-0.0857^{* *}$ \\
\hline & $(0.0319)$ & $(0.0319)$ & $(0.0374)$ \\
\hline \multirow[t]{2}{*}{ Inst. Democ. } & $0.0320^{* * *}$ & $0.0319^{* * *}$ & -0.00345 \\
\hline & $(0.00446)$ & $(0.00446)$ & $(0.00502)$ \\
\hline \multirow{2}{*}{ Market size * exporting status } & -0.0177 & -0.0183 & $-0.380^{* * *}$ \\
\hline & $(0.0958)$ & $(0.0959)$ & $(0.114)$ \\
\hline \multirow[t]{2}{*}{ Econ inst.* firm size } & $-0.0157^{* * *}$ & $-0.0157^{* * *}$ & $-0.0177^{* * *}$ \\
\hline & $(0.00253)$ & $(0.00254)$ & $(0.00300)$ \\
\hline \multirow{2}{*}{ Econ inst. ${ }^{*}$ exporting status } & 0.00208 & 0.00207 & $-9.43 e-05$ \\
\hline & $(0.00164)$ & $(0.00164)$ & $(0.00195)$ \\
\hline \multirow[t]{2}{*}{ Inst. Democ. ${ }^{*}$ exporting status } & -0.00969 & -0.00957 & 0.0169 \\
\hline & $(0.0118)$ & $(0.0118)$ & $(0.0140)$ \\
\hline \multirow[t]{2}{*}{ Inst. Democ. ${ }^{*}$ firm size } & $0.0974^{* * *}$ & $0.0968^{* * *}$ & $-0.0661^{*}$ \\
\hline & $(0.0336)$ & $(0.0336)$ & $(0.0391)$ \\
\hline \multirow[t]{2}{*}{ Southern Africa } & -0.194 & -0.197 & $-1.212^{* * *}$ \\
\hline & $(0.124)$ & $(0.124)$ & $(0.117)$ \\
\hline \multirow[t]{2}{*}{ Eastern Africa } & $6.535^{* * *}$ & $6.518^{* * *}$ & $-0.364^{*}$ \\
\hline & $(0.205)$ & $(0.205)$ & $(0.198)$ \\
\hline \multirow[t]{2}{*}{ Western Africa } & $4.717^{* * *}$ & $4.702^{* * *}$ & 0.0271 \\
\hline & $(0.142)$ & $(0.142)$ & $(0.130)$ \\
\hline \multirow[t]{2}{*}{ Constant } & $13.19^{* * *}$ & $15.20^{* * *}$ & $26.42^{* * *}$ \\
\hline & $(1.072)$ & $(1.303)$ & $(0.962)$ \\
\hline \multirow[t]{2}{*}{ Sigma u } & & $2.817^{* * *}$ & \\
\hline & & $(0.604)$ & \\
\hline Sigma e & $3.436^{* * *}$ & $3.437^{* * *}$ & $4.094^{* * *}$ \\
\hline & $(0.0212)$ & $(0.0212)$ & $(0.0253)$ \\
\hline Rho & & $0.4018^{* * *}(0.1031)$ & \\
\hline Time-Variant Factor & $x$ & - & - \\
\hline Observations & 13,097 & 13,097 & 13,097 \\
\hline Number of year & 11 & 11 & 11 \\
\hline
\end{tabular}

Source: Authors' Calculations.

Note: Standard errors in parentheses ${ }^{* * *} \mathrm{p}<0.01,{ }^{* *} \mathrm{p}<0.05,{ }^{*} \mathrm{p}<0.1$. 
The results of the unconditional fixed-effect and random-effect Tobit regression models, show that the models produce the same results in terms of sign, size and significance. This implies that the unconditional fixed-effect Tobit regression model is neither more efficient nor more consistent than the random effect model and vice versa. Given the significance of rho, it could be stated that the panel-level variance component is important and the panel estimator is different from the pooled estimator. Thus, random effect estimates could be considered appropriate here.

In Table 3, it is observed that in the random-effect Tobit model, economic institutions, a fair court system and institutionalized democracy positively affect the market power of the four biggest firms, which implies that the firms may have co-opted these institutions. But if the quality of economic institutions and size of firms increase jointly, then the market power held by the four biggest firms reduces by 1.57 percent. This indicates that as both economic institution and other firms become stronger, competition improves in SSA. However, as democracy becomes more institutionalized and the size of firms goes up concurrently, market power of the four firms is found to increase by 9.74 percent. This could be also related to improved competition which compels the biggest to lobby political office holders so as to maintain their dominance of the market in the region.

The random-effect Tobit model of Table 3 also shows that expansion in the size of the domestic market increases the market power of the four biggest firms. This is clear as market leaders always seek to take advantage of any increase in the quantity demanded for products in their industries in order to maintain and sustain their leadership in the market. The model reveals further that sales' share of imported raw materials negatively affects the firms' market power, which implies that upswing in the sales' share of imported raw materials causes a decrease in market share of the four biggest firms by 0.843 percent. This could be due to the high cost of importing raw materials which thereby reduce the competitive advantage of the biggest firms. However, the model shows that labor cost has a positive and significant effect on the market share of the four biggest firms as it increases their market share by 9.39 percent, which may be due to economies of scale.

As firms become more experienced (represented by an increase in age) and physical capital increases, the market power of the four biggest firms goes up by 1.51 and 4.83 percent respectively. Similarly, an increase in the size of firms and being domestic and privately-owned raises the 
market power held by the four biggest firms in the region. Finally, the market power held by the four biggest firms is higher in Eastern and Western Africa than that of Central Africa.

To check the robustness of our findings, we estimated the standard linear fixed effect, the random effect and pooled regression models. The results of the robust test of HHI models are presented in Table 4 and the findings of the standard linear fixed effect model are similar to those of the fixed and random effect Tobit regression models reported in Table 2. The Hausman test was conducted and the result implies that the standard linear fixed effect model is more efficient or appropriate than the random effect model. Therefore, this corroborates the reliability of our findings in the tables. Further, the findings of ordinary random effect and pooled regression models in Table 4 are similar to each other and to those of the pooled Tobit regression model of Table 2. The rho result in Table 2 confirms that the findings of fixed- and random-effect Tobit regression models are consistent with each other.

Also, the findings of the standard linear random effect and pooled regression models in Table 5 are similar to each other and to those of the pooled Tobit regression model of Table 3. And the insignificance of the Breusch and Pagan Langrangian Multiplier Test shows that the random effect is not important, which means the random effect panel estimator in this case is different from the pooled estimator. However, the rho result in Table 3 shows otherwise, and this still confirms that the findings of fixed and random-effect Tobit regression models are consistent with each other. 
Table 4: Robustness Check of HHI Models

\begin{tabular}{|c|c|c|c|}
\hline & HHI Robust & & \\
\hline Variables & FE & RE & Pooled \\
\hline Age & $\begin{array}{c}-1.65 e-05^{* * *} \\
(4.01 e-06)\end{array}$ & $\begin{array}{c}-2.48 \mathrm{e}-05^{* * *} \\
(4.46 \mathrm{e}-06)\end{array}$ & $\begin{array}{c}-2.48 \mathrm{e}-05^{* * *} \\
(4.46 e-06)\end{array}$ \\
\hline Lab cost $(\log )$ & $\begin{array}{c}0.000280^{* * *} \\
(2.92 \mathrm{e}-05)\end{array}$ & $\begin{array}{l}8.66 \mathrm{e}-05^{* * *} \\
(3.00 \mathrm{e}-05)\end{array}$ & $\begin{array}{c}8.66 \mathrm{e}-05^{* * *} \\
(3.00 \mathrm{e}-05)\end{array}$ \\
\hline Phy capital (log) & $\begin{array}{c}5.15 \mathrm{e}-05 \\
(3.15 \mathrm{e}-05)\end{array}$ & $\begin{array}{c}0.000122^{* * *} \\
(3.55 \mathrm{e}-05)\end{array}$ & $\begin{array}{c}0.000122^{* * *} \\
(3.55 \mathrm{e}-05)\end{array}$ \\
\hline Firm size & $\begin{array}{c}-0.000778^{* * * *} \\
(0.000250)\end{array}$ & $\begin{array}{c}-0.000673^{* *} \\
(0.000279)\end{array}$ & $\begin{array}{c}-0.000673^{* *} \\
(0.000279)\end{array}$ \\
\hline Sales' Prop. of Imported r/w & $\begin{array}{l}6.56 \mathrm{e}-06^{* * *} \\
(2.03 \mathrm{e}-06)\end{array}$ & $\begin{array}{c}2.14 \mathrm{e}-05^{* * *} \\
(2.27 \mathrm{e}-06)\end{array}$ & $\begin{array}{c}2.14 \mathrm{e}-05^{* * *} \\
(2.27 \mathrm{e}-06)\end{array}$ \\
\hline Exporting status & $\begin{array}{c}0.00948^{* * *} \\
(0.00298)\end{array}$ & $\begin{array}{l}0.0164^{* * *} \\
(0.00335)\end{array}$ & $\begin{array}{l}0.0164^{* * *} \\
(0.00335)\end{array}$ \\
\hline Domestic Market size & $\begin{array}{c}-0.00204^{* * *} \\
(8.25 \mathrm{e}-05)\end{array}$ & $\begin{array}{c}-0.00221^{* * *} \\
(6.80 \mathrm{e}-05)\end{array}$ & $\begin{array}{c}-0.00221^{* * *} \\
(6.80 \mathrm{e}-05)\end{array}$ \\
\hline Govt ownership & $\begin{array}{l}-0.000364 \\
(0.000351)\end{array}$ & $\begin{array}{l}-0.000253 \\
(0.000395)\end{array}$ & $\begin{array}{l}-0.000253 \\
(0.000395)\end{array}$ \\
\hline Domestic Priv. Own & $\begin{array}{l}-0.000104 \\
(0.000174)\end{array}$ & $\begin{array}{l}-0.000367^{*} \\
(0.000195)\end{array}$ & $\begin{array}{l}-0.000367^{*} \\
(0.000195)\end{array}$ \\
\hline Econ inst. & $\begin{array}{c}2.51 \mathrm{e}-05 \\
(1.64 \mathrm{e}-05)\end{array}$ & $\begin{array}{c}-6.97 e-05^{* * *} \\
(1.80 e-05)\end{array}$ & $\begin{array}{c}-6.97 e-05^{* * * *} \\
(1.80 e-05)\end{array}$ \\
\hline Court sys fairness & $\begin{array}{l}-1.43 e-05 \\
(5.67 e-05)\end{array}$ & $\begin{array}{c}-0.000228^{* * *} \\
(6.30 \mathrm{e}-05)\end{array}$ & $\begin{array}{c}-0.000228^{* * *} \\
(6.30 \mathrm{e}-05)\end{array}$ \\
\hline Inst. Democ. & $\begin{array}{l}4.04 \mathrm{e}-05^{* * *} \\
(7.99 \mathrm{e}-06)\end{array}$ & $\begin{array}{c}3.42 \mathrm{e}-05^{* * *} \\
(8.54 \mathrm{e}-06)\end{array}$ & $\begin{array}{c}3.42 \mathrm{e}-05^{* * *} \\
(8.54 \mathrm{e}-06)\end{array}$ \\
\hline Market size ${ }^{*}$ exporting status & $\begin{array}{c}-0.000592^{* * *} \\
(0.000169)\end{array}$ & $\begin{array}{c}-0.000989^{* * *} \\
(0.000191)\end{array}$ & $\begin{array}{c}-0.000989^{* * * *} \\
(0.000191)\end{array}$ \\
\hline Econ inst. ${ }^{*}$ firm size & $\begin{array}{c}3.79 \mathrm{e}-06 \\
(4.55 \mathrm{e}-06)\end{array}$ & $\begin{array}{c}6.42 \mathrm{e}-06 \\
(5.10 \mathrm{e}-06)\end{array}$ & $\begin{array}{c}6.42 \mathrm{e}-06 \\
(5.10 \mathrm{e}-06)\end{array}$ \\
\hline Econ inst. * exporting status & $\begin{array}{l}-1.76 e-06 \\
(2.93 e-06)\end{array}$ & $\begin{array}{c}-1.77 \mathrm{e}-06 \\
(3.31 \mathrm{e}-06)\end{array}$ & $\begin{array}{l}-1.77 \mathrm{e}-06 \\
(3.31 \mathrm{e}-06)\end{array}$ \\
\hline Inst. Democ.. * exporting status & $\begin{array}{l}3.88 \mathrm{e}-05^{*} \\
(2.11 \mathrm{e}-05)\end{array}$ & $\begin{array}{c}3.03 \mathrm{e}-05 \\
(2.37 \mathrm{e}-05)\end{array}$ & $\begin{array}{c}3.03 \mathrm{e}-05 \\
(2.37 \mathrm{e}-05)\end{array}$ \\
\hline Inst. Democ.. ${ }^{*}$ firm size & $\begin{array}{c}-0.000236^{* * *} \\
(5.79 \mathrm{e}-05)\end{array}$ & $\begin{array}{c}-0.000180^{* * * *} \\
(6.37 \mathrm{e}-05)\end{array}$ & $\begin{array}{c}-0.000180^{* * * *} \\
(6.37 \mathrm{e}-05)\end{array}$ \\
\hline Southern Africa & $\begin{array}{l}-0.000576 \\
(0.000363)\end{array}$ & $\begin{array}{c}-0.00200^{* * *} \\
(0.000331)\end{array}$ & $\begin{array}{c}-0.00200^{* * *} \\
(0.000331)\end{array}$ \\
\hline Eastern Africa & $\begin{array}{c}-0.00275^{* * *} \\
(0.000214)\end{array}$ & $\begin{array}{c}-0.00295^{* * *} \\
(0.000193)\end{array}$ & $\begin{array}{c}-0.00295^{* * *} \\
(0.000193)\end{array}$ \\
\hline Western Africa & $\begin{array}{c}-0.000806^{* * * *} \\
(0.000248)\end{array}$ & $\begin{array}{c}-0.000565^{* * *} \\
(0.000215)\end{array}$ & $\begin{array}{c}-0.000565^{* * * *} \\
(0.000215)\end{array}$ \\
\hline Constant & $\begin{array}{l}0.0385^{* * *} \\
(0.00172)\end{array}$ & $\begin{array}{l}0.0484^{* * *} \\
(0.00162)\end{array}$ & $\begin{array}{l}0.0484^{* * *} \\
(0.00162)\end{array}$ \\
\hline Observations & 13,295 & 13,295 & 13,295 \\
\hline Number of year & 11 & 11 & \\
\hline $\begin{array}{l}\text { Hausman Test } \\
\text { Breusch and Pagan LM Test }\end{array}$ & \multicolumn{2}{|c|}{$2046.58[0.0000]^{* * * *}$} & $0.0000[1.0000]$ \\
\hline
\end{tabular}

Source: Authors' Calculations.

Notes: Standard errors in parentheses, probability values in [ ], ${ }^{* *} \mathrm{p}<0.01,{ }^{* *} \mathrm{p}<0.05,{ }^{*} \mathrm{p}<0.1$. 
Table 5: Robustness Check of CR Models

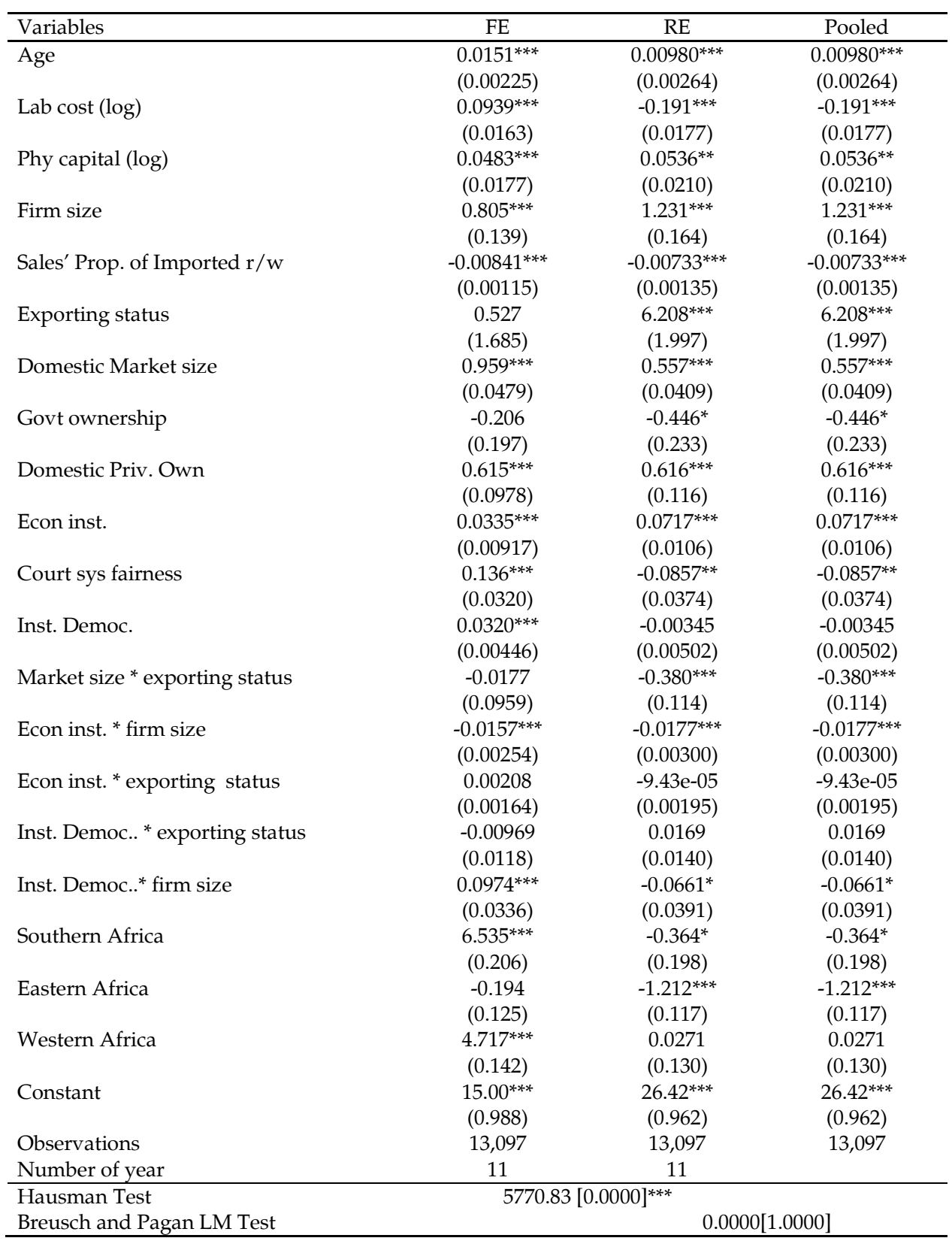

Source: Authors' Calculations.

Notes: Standard errors in parentheses, probability values in [ ], ${ }^{* * *} \mathrm{p}<0.01,{ }^{* *} \mathrm{p}<0.05,{ }^{*} \mathrm{p}<0.1$

Generally, the findings signify that institutions significantly matter in determining market power among firms in SSA. However, the influence of institutions vary greatly depending on the circumstances. When all 
firms are considered in the analysis, the impacts of institutions are found to fairly meet theoretical expectations. However, institutionalized democracy is found to be encouraging firms to dominate the market, which could be related to political patronage and lobbyist activities of some firms during and after elections.However, as democracy becomes more institutionalized and there is greater growth of firms, there is less chance of firms dominating the market (see Memanova \& Mylonidis, 2019). This is of course the combined effect of highly institutionalized democracy and increased competitive capability of many firms.

Conversely, the findings show that the four biggest firms exploited the weak institutions to dominate the industries in the region which may be through lobbyist and collusive activities, and unsubstantiated innovation and invention 9 . Again, the results show that as economic institutions become stronger and firms grow simultaneously bigger, there is a smaller possibility of the four biggest firms dominating the market. This could be linked to the fact that many firms have grown adequately to compete with the biggest firms and at the same time economic institutions guarantee an enabled 'playing field' for all the firms in the region through freedom of property rights, investment, monetary accessibility and fiscal freedom, which together encourage the entry of new firms into many industries or markets. Thus, the entry of new firms reduces the market power of the existing firms. It is noteworthy that market size has a significant impact on market power. Therefore, with large markets firms do not concern themselves too much to dominate the market.

\section{Conclusion and Policy Recommendations}

This paper examines the sources of market power among firms in SSA. To actualize this objective, a firm-level unbalanced panel dataset (Enterprise Surveys) by the World Bank was used and analysed using a random-effects Tobit regression model. The study finds that a significant number of firms hold less than 20 percent of the markets with a few firms holding between 20 and 60 percent of the markets. But there are a small number of firms holding between 70 and 99 percent of the markets in SSA. When high institutionalized democracy is supported by the growth of firms, then market power is reduced. Conversely, when high institutionalized democracy is supported by high exports, the market power held by some firms increases and this could be said to support the findings of Adebayo and Adeniji (2018).

\footnotetext{
${ }^{9}$ Patent right is usually granted to firms that innovate and/or invent.
} 
Other factors determining the firms' market power in SSA countries include domestic market size, age of firms, labor costs, exporting capacity, proportion of imported raw materials, overall market size, and regional effects. Labor costs, proportion of imported raw materials and exporting status positively affect market power, while the size of firms, domestic market size, overall market size, age of firms, and regional factors (due to lack of or weak competition policies) negative significant impact market power as established by Vickers (2005).

Similarly, the study established that economic, legal and political institutions encourage the four biggest firms to dominate their respective industries as they collude or form a cartel to collectively innovate or invent in their respective areas of businesses - which paves the way for them to gain market power easily. The study also found that as economic institutions become stronger and firms also grow, market domination by the four biggest firms is curtailed, perhaps through easy entry of the new firms into the markets - which can be explained as a clear case of weak legal and political institutions that do not properly regulate cartel or collusive activities in the markets. Also, the four biggest firms from Eastern and Western Africa dominate their markets more than those from Central and Southern Africa. This also confirms the finding of Vickers (2005), Adebayo and Adeniji (2018).

In line with the above findings, the study recommends some measures to improve the institutional framework in SSA. First, it is necessary to introduce legislations of competition in the region through constitutional amendments - particularly in Western Africa where there is evidence of weak institutions. Second, specific strong competitive policies on collusion, cartel, merger and acquisition should also be introduced in all countries such as the ones in South Africa, Togo and Kenya (Economic Commission of Africa, ECA, 2000). Third, there needs to be greater penalties for uncompetitive practices thereby serving as a deterrence. Fourth, competition commissions (such as the Zambian Competition Commission) ought to be introduced across all countries as an executive unit to monitor, control and prohibit acts or behavior which could adversely affect competition in the countries. Finally, in order to effectively implement the policies, there is a need to consider reducing the cost of doing business through infrastructural development. 


\section{References}

Adebayo, A., \& Adeniji, S. (2018). Integrated power market in West Africa: An overview. Journal of Public Policy and Administration, 2(3), 20-27.

Akande, J.O. (2018). Do competition, regulation and stability matter for efficiency in Sub-Saharan African banking sectors? Cogent Economics E Finance, 6(1). DOI: 10.1080/23322039.2018.1493667

Aghion, P., Bloom, N., Blundell, R., Griffith, R., \& Howitt, P. (2005). Competition and innovation: An inverted-U relationship. Quarterly Journal of Economics, 120(2), 701-728.

Ajide, F.M., Bankefa, O.I., \& Ajisafe, R.A. (2018). Criminal activities and firms' market power: Evidence from Nigerian banking industry. Global Business Review, 19(5), 1207-1223.

Asker, J., Collard-Wexler, A., \& De Loecker, J. (2017). Market power and production (mis) allocation: A study of the world oil market. Mimeo.

Asongu, S.A., Nwachukwu, J.C., \& Tchamyou, V.S. (2016). Information asymmetry and financial development dynamics in Africa. Review of Development Finance, 6(2), 126-138.

Asongu, S.A., \& Biekpe, N. (2018). ICT, information asymmetry and market power in African banking industry. Research in International Business and Finance, 44, 518-531.

Asongu, S.A., \& Odhiambo, N. M. (2019). Size, efficiency, market power, and economies of scale in the African banking sector. Financial Innovation, 5(1), 4.

Asongu, S.A., Le Roux, S., \& Tchamyou, V.S. (2019). Essential information sharing thresholds for reducing market power in financial access: a study of the African banking industry. Journal of Banking Regulation, 20(1), 34-50.

Barthwall, R. (2010). Industrial economics: An introductory textbook (3rd ed.). New Delhi: New Age International Publishers.

Bikker, J. A., \& Haaf, K. (2002). Measures of competition and concentration in the banking industry: A review of the literature. Economic $\mathcal{E}$ Financial Modelling, 9(2), 53-98. 
Bilotkash, V. (2007). Asymmetric regulation and airport dominance in internal aviation: Evidence from the London-New York market. South Economic Journal, 74, 305-523.

Bilotkash, V., \& Lakew, P.A. (2014). On the sources of market power in the airline industry: Panel data evidence from the US airports. Transportation Research, 59, 288-305.

Berger, D.W., Herkenhoff, K.F., \& Mongey, S. (2019). Labor market power (No. w25719). National Bureau of Economic Research.

Borenstein, S. (1991). Dominant firm advantage in the multi-product industries: Evidence from US airlines. Quarterly Journal of Economics, 106(4), 1237-1266.

Bresnahan, T. F. (1989). Empirical studies of industries with market power. Handbook of Industrial Organization, 2, 1011-1057.

Brezina, I., Pekar, J., Cickova, Z. and Reiff, M. (2016). Herfindahlhirschman16index level of concentration values modification and analysis of their change. Central European Journal of Operations Research, 24(1), 49-72.

Cabral, M.B. (2000). Introduction to industrial organisation. Cambridge: MIT Press.

Cameron, A.C., \& Trivedi, P.K. (2005). Microeconometrics: Methods and applications. Cambridge: Cambridge University Press.

Center for Systemic Peace. (2017). Polity IV dataset. Maryland: Center for Systemic Peace.

Chen, Y., \& Yu, X. (2018). Does the centralized slaughtering policy create market power for pork industry in China? China Economic Review, 50, 59-71.

Ciriani, S., \& Lebourges, M. (2016). The role of market power in economic growth: An analysis of the differences between EU and US competition policy theory, practice and outcomes. European Journal of Government and Economics, 5(1), 5-28.

Cotterill, R. W. (1986). Market power in the retail food industry: Evidence from Vermont. The Review of Economics and Statistics, 379-386. 
Cruz-García, P., de Guevara, J. F., \& Maudos, J. (2017). The evolution of market power in European banking . Finance Research Letters, 3(2), 43-67.

Dafny, L. S. (2005). Games hospitals play: Entry deterrence in hospital procedure markets. Journal of Economics \& Management Strategy, 14(3), 513-542.

Davidsson, P., \& Henrekson, M. (2002). Determinants of the prevalence of start-ups and high-growth firms. Small Business Economics, 19(2), 81-104.

De Loecker, J., \& Eeckhout, J. (2017). The rise of market power and the macroeconomic implications (No. w23687). National Bureau of Economic Research.

De Loecker, J., \& Van Biesebroeck, J. (2016). Effect of international competition on firm productivity and market power (No. w21994). National Bureau of Economic Research.

De Loecker, J., \& Eeckhout, J. (2018). Global market power (No. w24768). National Bureau of Economic Research.

Delis, M. D., Kokas, S., \& Ongena, S. (2016). Foreign ownership and market power in banking: Evidence from a world sample. Journal of Money, Credit and Banking, 48(2-3), 449-483.

Diez, M. F., Leigh, M. D., \& Tambunlertchai, S. (2018). Global market power and its macroeconomic implications. International Monetary Fund.

Dixit, A. (1980). The role of investment in entry deterrence. The Economic Journal, 90(357), 95-106.

Dunn, A., \& Shapiro, A. H. (2012). Physician market power and medical-care expenditures (Working Paper No. 127). Bureau of Economic Analysis.

Economic Commission of Africa (ECA). (2000). Trade and competition policy in the framework of African countries. Geneva: UNCTAD.

Egarius, D., \& Weill, L. (2016). Switching costs and market power in the banking industry: The case of cooperative banks. Journal of International Financial Markets, Institutions and Money, 42, 155-165. 
Gaynor, M., Ho, K., \& Town, R.J. (2015). The industrial organization of health-care markets. Journal of Economic Literature, 53(2), 235-284.

Goolsbee, A., \& Syverson, C. (2008). How do incumbents respond to the threat of entry? Evidence from the major airlines. Quarterly Journal of Economics, 123(4), 1611-1633.

Golombek, R., Irarrazabal, A.A., \& Ma, L. (2018). OPEC's market power: An empirical dominant firm model for the oil market. Energy Economics, 70, 98-115.

Grau, A., \& Hockmann, H. (2018). Market power in the German dairy value chain. Agribusiness, 34(1), 93-111.

Hart, P. E. (1971). Entropy and other measures of concentration. Journal of the Royal Statistical Society, Series A (General), 73-85.

Henrekson, M. (2005). Entrepreneurship: a weak link in the welfare state. Industrial and Corporate Change, 14(3), 437-467.

Henrekson, M., \& Johansson, D. (1999). Institutional effects on the evolution of the size distribution of firms. Small Business Economics, 12(1), 11-23.

Henrekson, M., \& Rosenberg, N. (2001). Designing efficient institutions for science-based entrepreneurship: Lesson from the US and Sweden. The Journal of Technology Transfer, 26(3), 207-231.

Herfindahl, O.C. (1950). Concentration in the US steel industry. Columbia: Columbia University.

Hintermann, B. (2011). Market power, permit allocation and efficiency in emission permit markets. Environmental and Resource Economjics, 49(3), 327-349.

Hirschman, A.O. (1964). The paternity of an index. American Economic Review, 54(5), 761-762.

Horvath, J. (1970). Suggestion for comprehensive measures for concentration. Southern Economic Journal, 36, 446-452.

Kim, E. H., \& Singal, V. (1993). Mergers and market power: Evidence from the airline industry. American Economic Review, 549-569. 
Klapper, L., Laeven, L., \& Rajan, R. (2006). Entry regulation as a barrier to entrepreneurship. Journal of Financial Economics, 82(3), 591-629.

Kovacic, W.E., \& Shapiro, C. (2000). Antitrust policy: A century of economic and legal thinking. Journal of Economic Perspectives, 14(1), 43-60.

Kwoka Jr, J.E. (1985). The Herfindahl index in theory and practice. Antitrust Bullion, 30, 915.

Lerner, A. P. (1934). Economic theory and socialist economy. The Review of Economic Studies, 2(1), 51-61.

Liski, M., \& Montero, J.P. (2011). Market power in an exhaustible resource market: The case of storable pollution permits. The Economic Journal, 121(551), 116-144.

Mankiw, N.G. (2012). Principles of Microeconomics (6th ed.). Mason, US: South-Western Cengage Learning.

Memanova, T., \& Mylonidis, N. (2019). Exploring the nexus between bank market power and exports. Economic Modelling, 7(2), 34-45.

Milgrom, P., \& Roberts, J. (1982). Limit pricing and entry under incomplete information: An equilibrium analysis. Econometrica: Journal of the Econometric Society, 443-459.

Morrison, C. J. (1990). Market power, economic profitability and productivity growth measurement: An integrated structural approach (No. w3355). National Bureau of Economic Research.

Naidu, S., Posner, E.A., \& Weyl, G. (2018). Antitrust remedies for labor market power. Harvard Labor Review, 132, 536.

Nevo, A. (2001). Measuring market power in the ready-to-eat cereal industry. Econometrica, 69(2), 307-342.

Pavic, I., Galetic , F., \& Piplica, D. (2016). Similarities and differences between the CR and $\mathrm{HHI}$ as an indicator of market concentration and market power. British Journal of Economics, Management and Trade, 13(1), 1-8. 
Prater , M.E., Casavant, K., Jessup, E., Blanton, B., Bahizi, P., Nibarger, D., \& Weingram, I. (2012). Rail competition changes since the Staggers Act. Journal of the Transportation Research Forum, 49(3), 45-67.

Reynolds, R.L. (2011). Basic microeconomics. Boise, Idaho, US: Textbook Equity Inc.

Rodrik, D. (2008). Second-best institutions. American Economic Review, 98(2), 100-104.

Roberts 1, S. (2004). The role for competition policy in economic development: The South African experience. Development Southern Africa, 21(1), 227-243.

Sitko, N.J., Burke, W.J., \& Jayne, T.S. (2018). The quiet rise of large-scale trading firms in East and Southern Africa. The Journal of Development Studies, 54(5), 895-914.

Seamans, R.C. (2012). Fighting city hall: Entry deterrence and technology upgrades in cable TV markets. Management Science, 58(3), 461-475.

Sylos-Labini, P. (1967). Oligopolio e pogresso tecnico. MIT press.

Tenn, S., \& Wendling, B.W. (2014). Entry threats and pricing in the generic drug industry. Review of Economics and Statistics, 96(2), 214-228.

The Heritage Foundation. (2017). Index of economic freedom . Washington, DC: The Center for International Trade and Economics.

United Nations Conference on Trade and Development, (2017). Trade and development report on market power and inequality, chapter, IV. New York: UNCTD.

Van Dender, K. (2007). Determinants of fares and operating revenues at US airports. Journal of Urban Economics, 62, 317-336.

Vickers, J. (2005). Abuse of market power. The Economic Journal, 15(1), 504520.

World Bank. (2017). Enterprise Surveys. Washington, DC: The World Bank Group. 
World Bank. (2017). World Development Indicators. Washinton, DC: The World Bank Group.

Zambrano, G. J. (2005). Modified maximum likelihood estimation of tobit models with fixed effects: Theory and an application to earnings equations. Investigaciones Económicas, Fundación SEPI, 29(3), 575-607. 


\section{Appendix}

\section{Appendix A: Description of Variables}

\begin{tabular}{|c|c|}
\hline Variable & Definition \\
\hline \multicolumn{2}{|l|}{ Dependent } \\
\hline Market Power & $\begin{array}{l}\text { Measured by Herfidahl-Hircschman Index (HHI) and } \\
\text { Concentration Ratio (CR) computed using firms' sales }\end{array}$ \\
\hline \multicolumn{2}{|l|}{ Explanatory } \\
\hline Age & $\begin{array}{l}\text { The number of years a firm has been in operation } \\
\text { (natural logarithm) }\end{array}$ \\
\hline Firm size & $\begin{array}{l}\text { Logarithmic of total number of firms' permanent and } \\
\text { full-time employees }\end{array}$ \\
\hline Domestic Ownership & $\begin{array}{l}\text { Dummy for the dominance of domestic private } \\
\text { ownership of the firms }\end{array}$ \\
\hline Government & $\begin{array}{l}\text { Dummy for the firms or portion of firms owned by } \\
\text { owned government }\end{array}$ \\
\hline Market Size & Logarithm of country's population \\
\hline Exporting status & Dummy for firms that export their output \\
\hline Imported Raw Materials & $\begin{array}{l}\text { Expenditure on imported raw materials as a } \\
\text { proportion of sales }\end{array}$ \\
\hline Economic Institutions & $\begin{array}{l}\text { Measured by the countries' average economic } \\
\text { freedom index }\end{array}$ \\
\hline Legal Institution & $\begin{array}{l}\text { Measured by a dummy for fairness of court system } \\
\text { whereby } 1 \text { for strongly disagree, } 2 \text { for tend to disagree, } \\
3 \text { for tend agree and, } 4 \text { for strongly agree that the court } \\
\text { system is fair, impartial and uncorrupted. }\end{array}$ \\
\hline Institutionalized Democracy & $\begin{array}{l}\text { Measured an index of how institutionalized a } \\
\text { country's democracy is. The index ranges from } 0 \text { for } \\
\text { completely weak to } 10 \text { for perfectly strong political } \\
\text { institution }\end{array}$ \\
\hline Central Africa & Dummy for firms operating in Central Africa \\
\hline Eastern Africa & Dummy for firms operating in Eastern Africa \\
\hline Western Africa & Dummy for firms operating in Western Africa \\
\hline Southern Africa & Dummy for firms operating in Southern Africa \\
\hline
\end{tabular}

Source: Authors' Calculations 


\section{Appendix B: Descriptive Statistics}

\begin{tabular}{|c|c|c|c|c|c|}
\hline \multicolumn{6}{|c|}{ Overall } \\
\hline Variables & Observation & Mean & $\begin{array}{c}\text { Standard } \\
\text { Dev }\end{array}$ & Min & Max \\
\hline Concentration R & 31,045 & 38.37553 & 14.31501 & 8.636711 & 100 \\
\hline HHI & 33,551 & .0045534 & .0068221 & .0001599 & .3366609 \\
\hline Age & 32,597 & 19.1433 & 13.37347 & 0 & 168 \\
\hline Lab Cost (log) & 17,778 & 15.03359 & 2.797457 & 6.907755 & 25.80839 \\
\hline Phy Cap (log) & 29,759 & 14.69501 & 3.153637 & 0 & 27.01484 \\
\hline Firm size & 33,167 & 2.686643 & 1.25106 & 0 & 11.06664 \\
\hline Imported r/m & 32,545 & 22.90073 & 26.83659 & 0 & 100 \\
\hline Exporting status & 33,509 & .0864842 & .281082 & 0 & 1 \\
\hline Market size & 33,551 & 17.75324 & 1.139574 & 13.07792 & 18.99435 \\
\hline Govt. Own & 33,550 & .0208048 & .1427324 & 0 & 1 \\
\hline Dom Priv Own & 33,027 & .9201865 & .2710083 & 0 & 1 \\
\hline Econ Institution & 33,551 & 54.67886 & 6.823078 & 22.1 & 68.5 \\
\hline Court Sys Fairn & 28,814 & 2.395641 & 1.017183 & 1 & 4 \\
\hline Inst. Democ. & 33,551 & 3.243957 & 10.40677 & -77 & 10 \\
\hline Eastern Africa & 33,551 & .2687252 & .4433033 & 0 & 1 \\
\hline Central Africa & 33,551 & .0776132 & .2675659 & 0 & 1 \\
\hline Southern Africa & 33,551 & .0584483 & .2345928 & 0 & 1 \\
\hline Western Africa & 33,551 & .5952133 & .490858 & 0 & 1 \\
\hline \multicolumn{6}{|c|}{ Central Africa } \\
\hline Concentr Ratio & 2,397 & 38.63603 & 1.081977 & 37.01178 & 40.7422 \\
\hline $\mathrm{HHI}$ & 2,604 & .0087635 & .002906 & .0045563 & .016073 \\
\hline Age & 2,526 & 17.78424 & 12.28528 & 0 & 114 \\
\hline Lab Cost (log) & 2,378 & 15.38401 & 2.482742 & 8.411833 & 25.35141 \\
\hline Phy Cap (log) & 2,547 & 14.5137 & 1.915485 & 2.995732 & 23.94214 \\
\hline Firm size & 2,590 & 2.754355 & 1.153462 & 0 & 8.517193 \\
\hline Imported $\mathrm{r} / \mathrm{m}$ & 2,602 & 27.53412 & 27.29746 & 0 & 100 \\
\hline Export status & 2,604 & .0837174 & .2770167 & 0 & 1 \\
\hline Market size & 2,604 & 17.24982 & .5887074 & 16.73552 & 18.09983 \\
\hline Govt. Own & 2,604 & .0280338 & .1651011 & 0 & 1 \\
\hline Dom Priv Own & 2,588 & .8531685 & .3540063 & 0 & 1 \\
\hline Econ Institution & 2,604 & 46.78568 & 5.872152 & 39.6 & 54.6 \\
\hline Court Sys Fairn & 2,456 & 1.939739 & .9421303 & 1 & 4 \\
\hline Inst. Democ. & 2,604 & 3.006528 & 2.191459 & 1 & 6 \\
\hline \multicolumn{6}{|c|}{ Eastern Africa } \\
\hline Concentr Ratio & 9,016 & 39.33413 & 7.840897 & 19.64077 & 100 \\
\hline $\mathrm{HHI}$ & 9,016 & .0051703 & .0032809 & .0015468 & .0173102 \\
\hline Age & 8,576 & 20.27624 & 16.30653 & 0 & 133 \\
\hline Lab Cost (log) & 6,821 & 15.13496 & 2.993181 & 6.907755 & 25.12999 \\
\hline Phy Cap (log) & 8,419 & 14.69095 & 2.118266 & 0 & 25.82861 \\
\hline Firm size & 8,829 & 3.010988 & 1.318202 & 0 & 10.30895 \\
\hline Imported $\mathrm{r} / \mathrm{m}$ & 8,755 & 26.72147 & 27.60933 & 0 & 100 \\
\hline Export status & 8,995 & .1136187 & .3173652 & 0 & 1 \\
\hline Dome mk size & 9,016 & 17.23844 & .704514 & 16.03808 & 18.41457 \\
\hline Govt. Own & 9,015 & .014975 & .1214596 & 0 & 1 \\
\hline Dom Priv Own & 8,769 & .9054624 & .2925918 & 0 & 1 \\
\hline
\end{tabular}




\begin{tabular}{|c|c|c|c|c|c|}
\hline \multicolumn{6}{|c|}{ Overall } \\
\hline Variables & Observation & Mean & $\begin{array}{c}\text { Standard } \\
\text { Dev }\end{array}$ & Min & $\operatorname{Max}$ \\
\hline Econ Institution & 9,016 & 53.46977 & 10.24213 & 22.1 & 63.9 \\
\hline Court Sys Fairn & 7,854 & 2.406799 & .9556095 & 1 & 4 \\
\hline Inst. Democ. & 9,016 & 3.682786 & 2.843969 & 0 & 9 \\
\hline \multicolumn{6}{|c|}{ Southern Africa } \\
\hline Concentr Ratio & 1,358 & 38.99267 & .6588058 & 37.01178 & 40.7422 \\
\hline $\mathrm{HHI}$ & 1,961 & .0047724 & .0058747 & .0014934 & .0361381 \\
\hline Age & 1,956 & 26.48262 & 19.91925 & 2 & 149 \\
\hline Lab Cost $(\log )$ & 1,885 & 14.29894 & 2.302975 & 6.907755 & 21.69329 \\
\hline Phy Cap (log) & 1,664 & 13.99374 & 1.990115 & 4.382027 & 22.51503 \\
\hline Firm size & 1,947 & 3.606962 & 1.65519 & 0 & 11.06664 \\
\hline Imported $\mathrm{r} / \mathrm{m}$ & 1,961 & 22.75144 & 28.89438 & 0 & 100 \\
\hline Export status & 1,954 & .1596725 & .3663958 & 0 & 1 \\
\hline Dome mk size & 1,961 & 17.20656 & 1.127029 & 14.50385 & 17.70496 \\
\hline Govt. Own & 1,961 & .0081591 & .0899814 & 0 & 1 \\
\hline Dom Priv Own & 1,946 & .8766701 & .3289 & 0 & 1 \\
\hline Econ Institution & 1,961 & 64.08419 & 6.368682 & 49.7 & 68.5 \\
\hline Court Sys Fairn & 1,314 & 2.429224 & .9001641 & 1 & 4 \\
\hline Inst. Democ. & 1,961 & 8.922998 & .2666619 & 8 & 9 \\
\hline \multicolumn{6}{|c|}{ Western Africa } \\
\hline Concentr Ratio & 18,274 & 37.82254 & 17.79956 & 8.636711 & 100 \\
\hline HHI & 19,970 & .0037044 & .0081018 & .0001599 & .3366609 \\
\hline Age & 19,539 & 18.08701 & 10.73136 & 0 & 168 \\
\hline Lab Cost (log) & 6,694 & 15.01269 & 2.787106 & 6.907755 & 25.80839 \\
\hline Phy Cap (log) & 17,129 & 14.33413 & 1.661739 & 0 & 27.01484 \\
\hline Firm size & 19,801 & 2.442672 & 1.101548 & 0 & 8.723882 \\
\hline Imported $\mathrm{r} / \mathrm{m}$ & 19,227 & 20.54914 & 25.90379 & 0 & 100 \\
\hline Export status & 19,956 & .0674484 & .2508032 & 0 & 1 \\
\hline Dome mk size & 19,970 & 18.10498 & 1.217427 & 13.07792 & 18.99435 \\
\hline Govt. Own & 19,970 & .0237356 & .1522281 & 0 & 1 \\
\hline Dom Priv Own & 19,724 & .9398195 & .237827 & 0 & 1 \\
\hline Econ Institution & 19,970 & 55.3304 & 2.118205 & 48.7 & 61.3 \\
\hline Court Sys Fairn & 17,190 & 2.453112 & 1.046582 & 1 & 4 \\
\hline Inst. Democ. & 19,970 & 2.519129 & 13.18656 & -77 & 10 \\
\hline
\end{tabular}

Source: Authors' Calculations 


\section{Appendix C: Countries in the Panel Dataset}

\begin{tabular}{lll}
\hline Countries & Sub-Region & Years of Panel Surveys \\
\hline Angola & Central Africa & 2006,2010 \\
Benin & Western Africa & 2005,2009 \\
Burkina Faso & Western Africa & $2006,2009,2016$ \\
Cameroon & Central Africa & $2006,2009,2016$ \\
Cape Verde & Western Africa & 2006,2009 \\
Coted Ivoire & Western Africa & 2009,2016 \\
Democratic Republic & of & Central Africa \\
Congo (DRC) & & 2010,2013 \\
Ethiopia & Eastern Africa & \\
Ghana & Western Africa & 2011,2015 \\
Kenya & Eastern Africa & 2007,2013 \\
Lesotho & Southern Africa & 2007,2013 \\
Malawi & Eastern Africa & 2009,2016 \\
Mali & Western Africa & 2009,2014 \\
Niger & Western Africa & $2003,2007,2010$ \\
Nigeria & Western Africa & $2005,2009,2017$ \\
Rwanda & Eastern Africa & $2007,2009,2014$ \\
Senegal & Western Africa & 2006,2011 \\
South Africa & Southern Africa & 2003,2007 \\
Tanzania & Eastern Africa & 2003,2007 \\
Togo & Western Africa & 2006,2013 \\
Uganda & Eastern Africa & 2009,2016 \\
Zambia & Eastern Africa & 2006,2013 \\
Zimbabwe & Eastern Africa & 2007,2013 \\
\hline
\end{tabular}

Source: Authors' Calculations 


\section{Appendix D: Parts of Pairwise Correlation for Possibility of Causality}

\begin{tabular}{lcc}
\hline & HHI & CR \\
\hline HHI & 1.000 & \\
CR & -0.0004 & 1.0000 \\
Age & -0.0206 & -0.0541 \\
Lab cost $(\log )$ & 0.0796 & -0.0333 \\
Phy capital (log) & 0.0919 & -0.0055 \\
Firm size & 0.0379 & 0.0609 \\
Sales' Prop. of Imported r/w & 0.2278 & -0.0611 \\
Exporting status & 0.0456 & 0.0385 \\
Domestic Market size & -0.5330 & -0.0352 \\
Govt ownership & -0.0051 & 0.0072 \\
Domestic Priv. Own & -0.1079 & -0.0014 \\
Econ inst. & -0.0528 & -0.0008 \\
Court sys fairness & -0.0581 & 0.0014 \\
Inst. Democ. & -0.0044 & -0.0026 \\
Central Africa & 0.1790 & 0.0053 \\
Eastern Africa & 0.0548 & 0.0428 \\
Southern Africa & 0.0080 & 0.0092 \\
Western Africa & -0.1509 & -0.0462 \\
\hline
\end{tabular}

Source: Authors' Calculations 